\title{
Immunological evidence for the presence of an IgM-like immunoglobulin in the eggs of coho salmon Oncorhynchus kisutch
}

\author{
A. N. Yousif ${ }^{1, *}$, L. J. Albright ${ }^{1}$, T. P. T. Evelyn ${ }^{2}$ \\ ${ }^{1}$ Institute for Aquaculture Research, Department of Biological Sciences, Simon Fraser University, Burnaby, \\ British Columbia, Canada V5A 1S6 \\ ${ }^{2}$ Department of Fisheries and Oceans, Pacific Biological Station, Nanaimo, British Columbia, Canada V9R 5K6
}

\begin{abstract}
Western blot analysis of the yolk extract of coho salmon eggs revealed the presence of an immunoglobulin-like protein molecule that reacted with antibodies specific for coho serum immunoglobulin ( $\lg M)$. Sucrose gradient ultracentrifugation analysis of the yolk extract showed that the molecule 'sedimented' in a manner similar to bovine serum immunoglobulin lgG. This indicates that coho salmon eggs contain a low molecular weight form of serum IgM, perhaps a breakdown product, or a precursor of IgM. The precise function of the reported intra-ovum IgM-like protein is unknown.
\end{abstract}

KEY WORDS: IgM Immunoglobulin Salmonids $\cdot$ Eggs

\section{INTRODUCTION}

The salmonid embryo has little or no ability to display specific immunity due to immaturity of its lymphoid tissues (Ellis 1977). In contrast to mammals and fowl in which the embryo is protected by materno-fetal or biophysical barriers during the entire period of embryogenesis, embryonic development in oviparous fishes continues after hatching, at which stage the embryo is in direct contact with a potentially harmful environment. It is well known that maternal transfer of antibodies is mainly accomplished through the yolk sac, the placenta, or the neonate gut, depending on the animal species (Brambell 1970). The pathway of this transfer of immunity has been well studied in the chicken. Antibodies ( $\mathrm{IgG}$ ) in the blood of the hen are transferred to the oocyte via IgG receptors on the oocyte (Buxton 1952, Kramer \& Cho 1970, Rose et al. 1974)

Because fish larvae hatch into a hostile environment when their immunological capacity is still severely limited, it is reasonable to suggest that a mechanism of specific protection of maternal origin has also devel-

•E-mail: ayousif@sfu.ca oped in fishes. However, information about this subject is very limited. Preliminary results have been reported recently indicating that a maternal transfer of immunity may occur in some fishes (Van Loon et al. 1981, Bly et al. 1986, Mor \& Avtalion 1988, 1990, Shors \& Winston 1989, Kawahara et al. 1993) through the yolk sac, as in birds.

The purpose of the study reported here was to examine the eggs of coho salmon Oncorhynchus kisutch for maternal immunoglobulin (Ig).

\section{MATERIALS AND METHODS}

Eggs and preparation of yolk extract. Unfertilized, non-water-hardened eggs were obtained from ripe females of coho salmon that had returned from the sea to spawn in the Capilano River near Vancouver, British Columbia, Canada. The eggs were washed free of the ovarian fluid. Yolk extract (YE) was obtained following the method outlined in Yousif et al. (1994).

Protein concentration was determined according to the method of Bradford (1976), using bovine serum albumin as the standard. 
Sodium dodecyl sulfate-polyacrylamide gel electrophoresis (SDS-PAGE), and immunoblotting. The immunoglobulin in $5 \mathrm{ml}$ of normal coho serum was precipitated by adding $1.25 \mathrm{~g}$ of $\left(\mathrm{NH}_{4}\right)_{2} \mathrm{SO}_{4}(1.95 \mathrm{M})$, and incubating the mixture for $20 \mathrm{~h}$ at room temperature. The precipitated immunoglobulin was then harvested by centrifugation at $2500 \times g$ for $30 \mathrm{~min}$ at $4^{\circ} \mathrm{C}$. The precipitate was resuspended in phosphatebuffered saline (PBS, pH 7.1), and the process of precipitation was repeated twice before the suspension was finally dialysed against $\mathrm{PBS}$ at $4^{\circ} \mathrm{C}$ for $2 \mathrm{~d}$ to reduce the salt content. The preparation was finally stored at $4^{\circ} \mathrm{C}$ until used. Serum and YE proteins were then separated by SDS-PAGE (separating gel: linear gradient 5 to $12.5 \%$; stacking gel: $4.5 \%$ at $25 \mathrm{~mA}$ for 6 to $7 \mathrm{~h}$ ) under a denaturing system (with 2-mercaptoethanol) as outlined in Johnstone \& Thorpe (1987). Upon completion of electrophoresis, half of the gel was silver-stained (Wray et al. 1981) to ascertain whether proper separation of proteins had occurred, and the other half was equilibrated for $1 \mathrm{~h}$ in transfer buffer: $25 \mathrm{mM}$ Tris/192 mM glycine (pH 8.3) with $20 \%$ methanol. The separated proteins were then transferred electrophoretically onto a nitrocellulose (N/C) membrane (Bio-Rad, Richmond, CA, USA), using a transblot apparatus (LKB 2117-250 Novablot, Bromma, Sweden) at $0.8 \mathrm{~mA} \mathrm{~cm}^{-2}$ for $2 \mathrm{~h}$. All subsequent manipulations were performed at room temperature. After blocking unreacted sites on the $\mathrm{N} / \mathrm{C}$ membrane by immersion in a $3 \%$ solution ( $\mathrm{w} / \mathrm{v}$ ) of gelatin in Tris-buffered saline (TBS: $20 \mathrm{mM}$ Tris/500 mM NaCl, pH 7.5) for $1 \mathrm{~h}$ with gentle shaking, the N/C membrane was washed twice in Tween20-containing TBS (TTBS). It was then exposed to a solution of rabbit anti-coho IgM (diluted 1:250 in 1\% gelatin-TTBS = antibody buffer) for $2 \mathrm{~h}$ with gentle shaking. Control N/C membranes were treated with a similar dilution of preimmune rabbit serum. The $\mathrm{N} / \mathrm{C}$ membranes were washed twice in TTBS and then exposed to a solution of goat anti-rabbit IgG conjugated to horseradish peroxidase (HRP) (diluted 1:2000 in antibody buffer) for $1 \mathrm{~h}$ with gentle shaking. The solution was then discarded and the N/C was washed twice in TTBS and once in TBS. The N/C membrane was finally developed by addition of the HRP substrate (4-chloro-1-naphthol; Bio-Rad). Developed blots were kept in the dark until photographed.

Antisera. Antiserum to coho serum immunoglobulin (IgM, purified by the method of DeLuca et al. 1983) was induced in rabbits and generously provided by M. I. Velji, Simon Fraser University, Canada. The purity of coho IgM and the specificity of the induced antiserum were determined by comparing the number of protein bands that developed when a sample of ammo- nium-sulphate-precipitated coho normal serum was run in SDS-PAGE and silver stained to those bands that developed when the same sample was electroblotted, following SDS-PAGE, onto a N/C membrane, and the latter was probed with the rabbit antiserum. Goat anti-rabbit IgG conjugated to HRP was obtained from Bio-Rad.

Absorption of antibody activity. Heat-killed bacterial suspensions $(100 \mu \mathrm{l}$, absorbance $=5.0$ at $540 \mathrm{~nm}$ ) of selected virulent strains of Aeromonas salmonicida, Aeromonas hydrophila, Vibrio anguillarum, Vibrio ordalii, and Renibacterium salmoninarum were combined, placed in Eppendorf tubes, and centrifuged (Micro-Centrifuge, Model 235C, Fisher Scientific) for $10 \mathrm{~min}$ at room temperature. The bacterial pellet served as a solid phase for absorption of the antibody activity in the YE. This absorption was accomplished by 2 successive incubations (14 $\mathrm{h}$ at $\left.4^{\circ} \mathrm{C}\right)$ of $100 \mu \mathrm{l} \mathrm{YE}(650 \mu \mathrm{g}$ total protein) with the bacterial pellets. Following centrifugation $(10 \mathrm{~min}$ at room temp.), the supernatant was run in SDS-PAGE and silver stained.

Sucrose gradient centrifugation. A linear gradient of 5 to $42 \%$ sucrose $(12 \mathrm{ml})$ was formed in $14 \times 95 \mathrm{~mm}$ polyallomer tubes (Beckman, CA, USA) using a gradient maker. A sample of $100 \mu \mathrm{l}$ of $\mathrm{YE}\left(500 \mu \mathrm{g} \mathrm{ml} \mathrm{m}^{-1}\right.$ total protein) was gently layered on top of the sucrose gradient. As markers, bovine serum IgG and bovine serum IgM (Sigma) were prepared in PBS at a final concentration of $500 \mu \mathrm{g} \mathrm{ml}^{-1}$, and $100 \mu \mathrm{l}$ of each preparation were layered on top of the sucrose gradient. The tubes were then centrifuged $(183000 \times \mathrm{g}$ for 24 h at $4^{\circ} \mathrm{C}$ ) in a Beckman ultracentrifuge (model L2-65B, with SW-40 rotor). Fractions of $0.5 \mathrm{ml}$ were collected from the bottom of the tube with the aid of a peristaltic pump and a fraction collector. The refractive index of all fractions was determined using a refractometer (Carl Zeiss, Germany), and the readings were converted to sucrose concentration by reference to the International Critical Tables (1926) of sucrose. Proteins in the fractions were detected using SDSPAGE

\section{RESULTS}

Fig. 1 depicts the separation of coho salmon serum and YE proteins by linear gradient SDS-PAGE. Our preliminary trials with YE suggested the use of a linear gradient ( 5 to $12.5 \%$ ), or a separating gel the upper portion of which contained $\leq 7.5 \%$ acrylamide in order to reveal all the proteins present in coho eggs. Good seperations were only achieved by first removing all lipophilic substances and carotinoids from the eggs. 


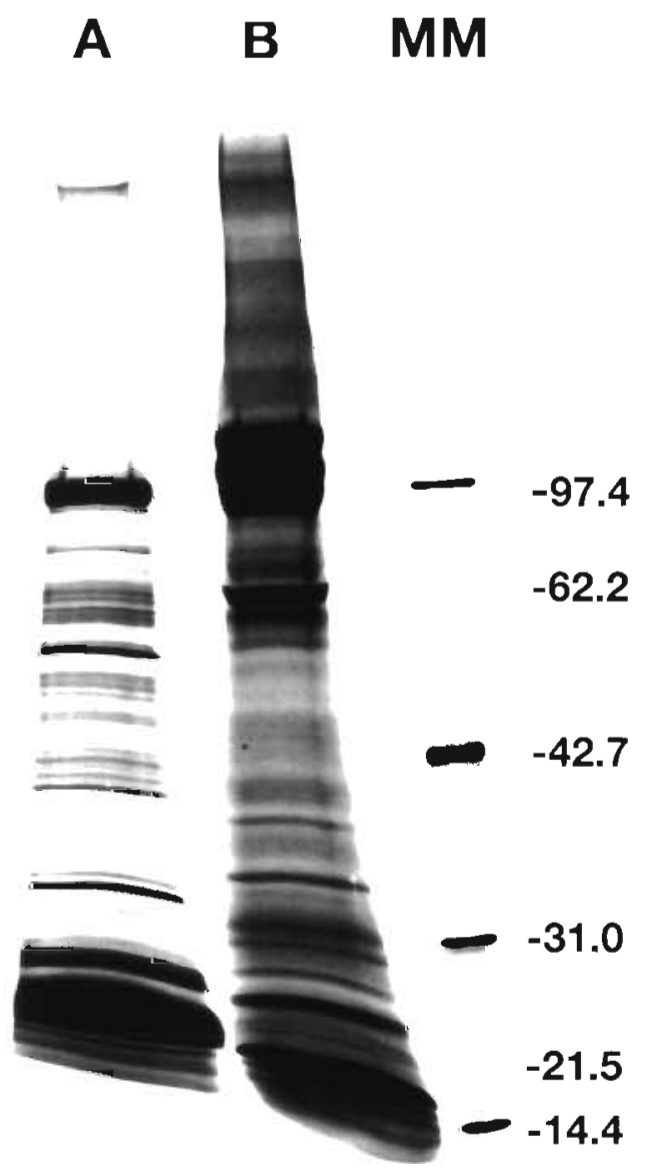

Fig. 1 Electrophoretic patterns of (A) coho salmon yolk extract, (B) normal serum. MM: Bio-Rad Low Molecular Weight Standards. Reduced (2-mercaptoethanol) samples $(10 \mu \mathrm{g}$ total protein per lane) were run on a 5 to $12.5 \%$ gradient SDS-polyacrylamide gel, and silver stained

The specificity of the rabbit antiserum for coho IgM was indicated by the appearance of 2 major bands on the $\mathrm{N} / \mathrm{C}$ membrane when the latter was probed with the polyclonal antiserum in the Western blot technique (Fig. 2A). By virtue of their size, and therefore their mobility in SDS-PAGE, these 2 bands were considered to be the heavy and light chains of the fish tetrameric immunoglobulin molecules in serum.

When electroblotted proteins of the YE were reacted with rabbit anti-coho IgM, the antiserum recognized, with different degrees of reactivity, 3 bands on the N/C membrane (Fig. 2B, Lane 1). In addition to 2 broad bands, 1 narrow band appeared at the upper part of the membrane. This band corresponded to a low mobility protein ( $\geq 200 \mathrm{kDa}$, the largest molecular mass marker used) that appeared near the origin of the gel in SDSPAGE (Fig. 1A). The 3 reacting proteins of YE were initially considered either (1) to be due to a low molecular weight form of serum IgM and its breakdown products, or (2) to be non-specific factors such as lectins which are known to bind to HRP and serum globulins (GilboaGarber et al. 1977, Lis \& Sharon 1977). In order to resolve this question, YE samples were run in SDS-PAGE, followed by electroblotting of the separated proteins onto a N/C membrane. The blocked membrane was then cut into lanes and each lane was treated (1 h, with gentle shaking) in one of the following test solutions (TS; D-galactose, L-rhamnose, D-mannose, or N-acetyl D-galactosamine, each at $0.3 \mathrm{M}$ ), and subsequently probed with the rabbit anti-coho IgM as outlined before. The test solutions were prepared in the antibody buffer at a concentration that has been shown to inhibit a lectin from coho eggs (Yousif et al. 1994), as well as a lectin from other salmonid eggs (Ozaki et al. 1983).

The positive reactivity recorded at the upper part of the N/C membrane was not influenced by any of the sugars tested. However, the lower 2 broad bands were equally susceptible to $\mathrm{N}$-acetyl $\mathrm{D}$-galactosamine and D-mannose, and their non-specific reaction with the rabbit anti-coho IgM antibodies was substantially suppressed (Fig. 2B, Lanes 1 \& 2). It is noteworthy that N/C membranes probed with rabbit pre-immune serum instead of rabbit anti-coho IgM did not show any visible bands. On the basis of these results it was concluded that the high molecular weight band was likely an Ig-like protein, whereas the lower molecular weight bands, the reactivity of which was suppressed by treatment with monosaccharides, represented lectin-like proteins.

Efforts to absorb the Ig-like egg protein with selected species of bacterial fish pathogens were unsuccessful, and the Ig-like protein band was visible in SDS-PAGE of the supernatants from absorbed YE samples (results not shown).

Ultracentrifugation analysis of YE in the sucrose gradient resulted in fractionation of the proteins, and revealed the presence of the Ig-like protein which was localized at the protein layer that sedimented at the 17.0 to $20.0 \%$ sucrose area of the gradient (Fig. 3A). Bovine serum IgG also sedimented at the 20.0 to $21.5 \%$ sucrose area of the gradient (Fig. 3B). As expected, bovine serum IgM sedimented in areas of a higher sucrose concentration ( 33.0 to $34.5 \%$; Fig. $3 \mathrm{C}$ ).

\section{DISCUSSION}

Under normal circumstances fish are exposed to environmental antigens. In response, a single class of tetrameric immunoglobulin (IgM) molecules is produced and can be detected in the serum and mucus (Ellis 1982). Fish serum IgM is estimated to have a molecular weight of 600 to $800 \mathrm{kDa}$, depending on the species. However, under the reducing conditions of SDS-PAGE, the molecule in salmonids dissociates into 

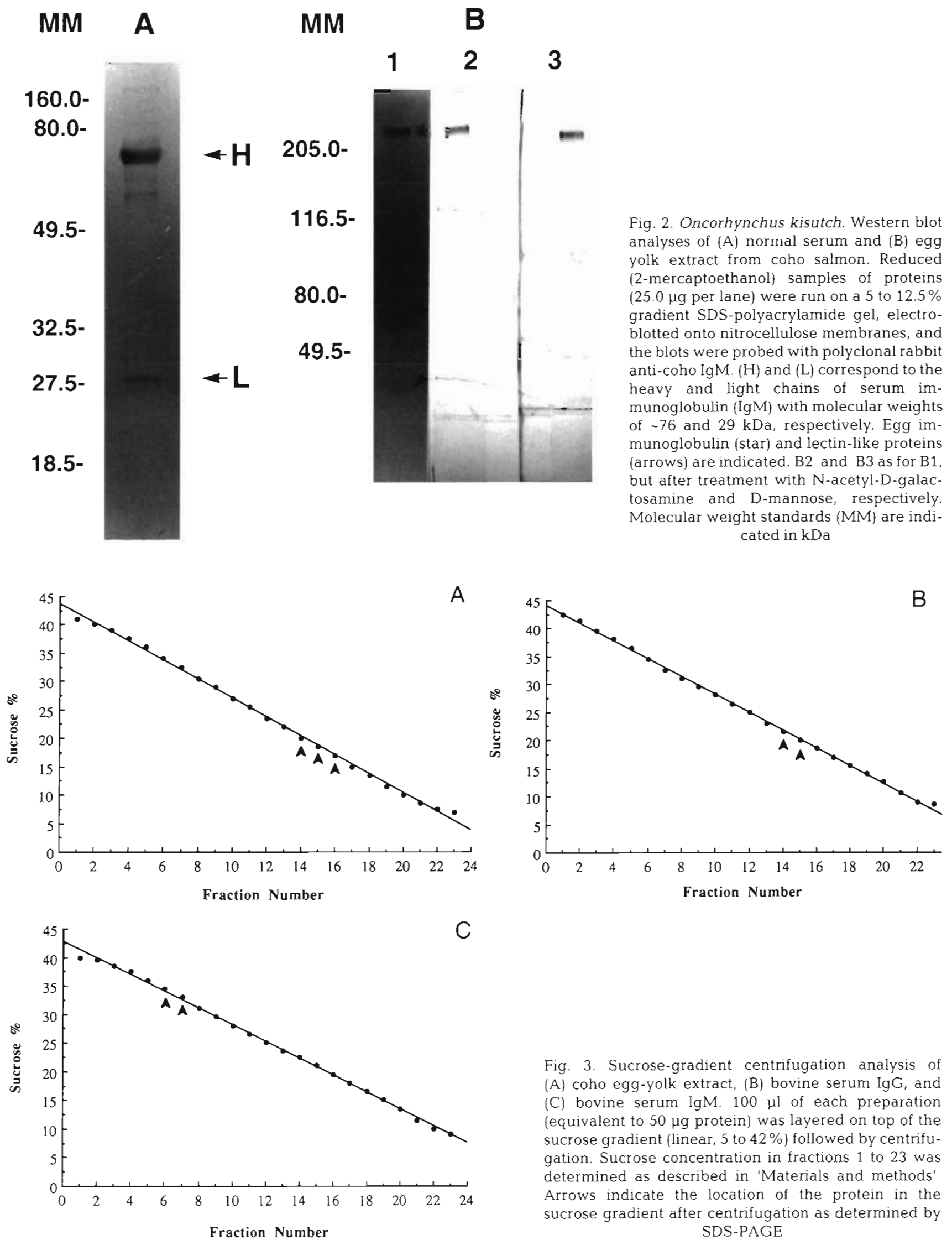

Fig. 3. Sucrose-gradient centrifugation analysis of (A) coho egg-yolk extract, (B) bovine serum IgG, and (C) bovine serum IgM. $100 \mu$ l of each preparation (equivalent to $50 \mu \mathrm{g}$ protein) was layered on top of the sucrose gradient (linear, 5 to $42 \%$ ) followed by centrifugation. Sucrose concentration in fractions 1 to 23 was determined as described in 'Materials and methods' Arrows indicate the location of the protein in the sucrose gradient after centrifugation as determined by SDS-PAGE 
heavy $(\mathrm{H})$ and light $(\mathrm{L})$ chains with estimated molecular weights of 76 and $29 \mathrm{kDa}$, respectively (Cisar \& Fryer 1974, Groberg 1982).

In this study, transfer of antibodies to offspring in coho salmon was investigated using SDS-PAGE and Western blot techniques. The results indicated the presence of an immunoglobulin (Ig)-like protein in unfertilized eggs of coho salmon, and the presence of 2 low molecular weight proteins that behaved like lectins because of their reactivity with sugars. This was in contrast to the study by Fuda et al. (1992), who recently demonstrated the presence of an egg IgM which had a molecular weight lower than that of serum IgM. Vertical transfer of protective immunoglobulins would not therefore be surprising, especially in view of the finding of immunoglobulin in the eggs/embryos of carp Cyprinus carpio (Van Loon et al. 1981), plaice Pleuronectes platessa (Bly et al. 1986), tilapia Oreochromis aureus (Mor \& Avtalion 1988, 1990), and rainbow trout Oncorhynchus mykiss (Shors \& Winston 1989, Castillo et al. 1993).

Egg homogenates of coho salmon separate into 3 different layers upon centrifugation: an upper fatty layer, a PBS-soluble fraction, and a pellet of broken egg shells (chorions). In this study, broken shells were removed by filtration through cotton cheesecloth, and the filtrate (fatty layer and PBS-soluble fraction) was subjected to a process of simultaneous precipitation and extraction using isopropyl alcohol and acetone. The PBS extract of the precipitate proved to contain an Ig-like protein. Similarly, Mor \& Avtalion (1990) showed that most of the antibody activity in the eggs of tilapia was located in the PBS-soluble fraction rather than in the upper fatty layer.

Sucrose gradient separation of the YE proteins followed by SDS-PAGE showed that the Ig-like protein sedimented at sucrose concentrations relatively similar to those of bovine serum IgG (Fig. 3A, B). Mor \& Avtalion (1988) showed that some of the antibody activity in tilapia eggs sedimented at a sucrose concentration similar to that of rabbit immunoglobulin (IgG). While direct evidence for the presence of coho immunoglobulin in the egg extract is not yet available, the antibody activity reported in this study strongly supports the premise that a maternal transfer of an immunoglobulin-like protein occurs. Because this antibody-like protein sedimented in a manner analogous to mammalian $\operatorname{IgG}(\mathrm{MW}=150$ to $160 \mathrm{kDa}$ ) rather than $\operatorname{IgM}(\mathrm{MW}=900$ $\mathrm{kDa}$ ), it is concluded that a low molecular weight form of serum IgM, perhaps a breakdown product or precursor of the IgM molecule, is transferred to eggs in coho salmon.

Failure to absorb the antibody activity in the eggs with heat killed bacterial cells of Aeromonas salmonicida, A. hydrophila, Vibrio anguillarum, V. ordalii or
Renibacterium salmoninarum is surprising because the coho would almost certainly have come in contact with one or more of these widespread pathogens. We can only conclude that the reported Ig-like protein in coho eggs was induced in the female fish as a result of exposure to some other antigen(s).

\section{LITERATURE CITED}

Bly JE, Grimm AS, Morris IG (1986) Transfer of passive immunity from mother to young in a teleost fish: haemagglutinating activity in the serum and eggs of plaice, Pleuronectes platessa L. Comp Biochem Physiol 84A(2):309-313

Bradford MM (1976) A rapid and sensitive method for the quantitation of microgram quantities of protein. Analyt Biochem 72:248-254

Brambell FWR (1970) The transmission of passive immunity from mother to young. In: Neuberger A, Tatum EL (eds) Frontier of biology, Vol 18. North-Holland Publishing Co. Amsterdam, p 385

Buxton A (1952) On the transference of bacterial antibodies from the hen to the chick. J gen Microbiol 7:268-286

Castillo A, Sanchez C. Dominguez J, Kattari SL, Villena AJ (1993) Ontogeny of $\lg M$ and $\operatorname{lgM}$-bearing cells in rainbow trout. Dev comp Immunol 17:419-424

Cisar JO, Fryer JL (1974) Characterization of anti-Aeromonas salmonicida antibodies from coho salmon. Infect Immunol 9:236-243

DeLuca D, Wilson M, Warr GW (1983) Lymphocyte heterogeneity in the trout Salmo gairdneri defined with monoclonal antibodies to IgM. Eur J Immunol 13:546-551

Ellis AE (1977) Ontogeny of the immune response in Salmo salar. Histogenesis of the lymphoid organs and appearance of membrane immunoglobulin and mixed leukocyte reactivity. In: Solomon JB, Horton JD (eds) Developmental immunology. Elsevier/North Holland Biomedical Press. Amsterdam, p 225-231

Ellis AE (1982) Differences between the immune mechanısm of fish and higher vertebrates. In: Roberts RJ (ed) Microbial diseases of fish. Academic Press, London, p 1-30

Fuda H. Hara A, Yamazaki F, Kabayayashi K (1992) A peculiar immunoglobulin ( $\mathrm{g} \mathrm{M}$ ) identified in eggs of chum salmon Oncorhynchus keta. Dev comp Immunol 16:415-423

Gilboa-Garber N, Nir-Mizrahi L, Garber N (1977) Haemagglutinins in extracts of Pseudomonas aeruginosa. Can J Biochem 55:975-981

Groberg W (1982) Infection and the immune response induced by Vibrio anguillarum in juvenile coho salmon Oncorhynchus kisutch. PhD thesis, Oregon State University, Corvallis

International Critical Tables (1926) McGraw-Hil, New York

Johnstone A, Thorpe R (1987) Polyacrylamide gel techniques. In: Johnstone A, Thorpe R (eds) Immunochemistry in practice, 2nd edn. Blackwell Scientific Publications, Oxford. p 148-182

Kawahara E, Inarimori T, Urano K, Nomura S, Takahashi Y (1993) Transfer of maternal immunity of white-spotted char Salvelinus leucomaenis against furunculosis. Nippon Suisan Gakk 59(3):567

Kramer TT, Cho HC (1970) Transfer of immunoglobulins and antibodies in the hen's egg. Immunology 19:157-167

Lis H, Sharon N (1977) Lectins: their chemistry and application to immunology. In: Sela $M$ (ed) The antigens, Vol 4 Academic Press, London, p 429-529 
Mor A, Avtalion RR (1988) Evidence of transfer of immunity from mother to eggs in tilapias. Bamidgeh 40(1):22-28

Mor A, Avtalion RR (1990) Transfer of antibody activity from immunized mother to embryo in tilapias. J Fish Biol 37 : $249-255$

Ozaki H, Ohwaki M, Fukada $T$ (1983) Studies on lectins of amago Oncorhynchus rhodurus. I. Amago ova lectin and its receptor on homologous macrophages. Dev comp Immunol 7:77-8?

Rose ME, Orland $E$, Buttress $N$ (1974) Immunoglobulin classes in the hen's egg: their segregation in yolk and white. Eur J Immunol 4:521-523

Shors ST, Winston V (1989) Neutralizing antibodies for infectious hematopoietic necrosis virus in eggs of steelhead

Editorial responsibility: Managing Editor trout (Salmo gairdneri). Am J Vet Res 50(2):232-234

Van Loon JJA, Van Oosterom R, Van Muiswinkel WB (1981) Development of the immune system in carp (Cyprinus carpio). In: Solomon JB (ed) Aspects of developmental and comparative immunology, Vol 1. Pergamon Press, Oxford, p $469-470$

Wray W, Boulikas T, Wray VP. Hancock R (1981) Silver staining of proteins in polyacrylamide gels. Analyt Biochem 118:197-203

Yousif AN, Albright LJ, Evelyn TPT (1994) Purification and characterization of a galactose-specific lectin from the eggs of coho salmon Oncorhynchus kisutch, and its interaction with bacterial fish pathogens. Dis aquat Org 20(2): $127-136$

Manuscript first received: March 15, 1995

Revised version accepted: July 3, 1995 